Andrzej Radkowski

DOI: http://dx.doi.org/10.12775/SEI.2017.008

Uniwersytet im. Adama Mickiewicza

\title{
Co Tocqueville mówi nam o demokracji - spojrzenie z perspektywy ekonomicznej teorii polityki
}

(What Tocqueville says to us about democracy: a look from the perspective of economic theory of democracy)

\begin{abstract}
Alexis de Tocqueville has been known chiefly as a liberal thinker and political theorist, but his economic concepts - albeit not systematized - are equally important. Using the framework of public choice theory, this article aims to reconstruct his widely known critique of democracy in the economic terms. Studying the growth of democratic governrment by notions of self-interest, rational ignorance, rational irrationality and other concepts borrowed from economics could allow one to acknowledge the importance of Tocqueville as a precursor of public choice theory and the need to remain doubtful in the face of democratic rule.
\end{abstract}

Keywords: Tocqueville, public choice theory, democracy, government growth

Krytyka demokracji w świecie, gdzie wszyscy - od liberałów do komunistów, od autokratów do anarchistów - powołują się na jej ideały oraz gdzie nawet w książkach mających stanowić analizę słabości ustroju reprezentacyjnego już pierwsze zdanie głosi, iż „demokracja to najbardziej rozsądna forma ustroju politycznego” (Marti 2010: 7), wydaje się przebrzmiała. Mając jednak na uwadze krytyczno-demaskatorskie funkcje nauk społecznych (zob. Berger 1995: 36-47), nie można dać się zwieść bon motowi Winstona Churchilla o tym, że „demokracja jest najgorszą formą rządu, jeśli nie liczyć wszystkich innych form, których próbowano od czasu do czasu”. Nie idzie tu o powrót do tradycjonalistycznej czy legitymistycznej substancjalnej negacji demokracji jako ustroju wręcz metafizycznie złego i niereformowalnego (Bartyzel 2009: 11), ale o zwrócenie się do ustaleń współczesnej ekonomii i socjologii, w szczególności do - czerpiącego z dorobku ekonomii neoklasycznej i teorii racjonalnego wyboru - interdyscyplinarnego projektu zwanego szkołą wyboru publicznego (public choice), w celu wykrycia realnych słabości rządów większości, których nie da się zbyć formułką „na błędy demokracji - więcej demokracji”. Matrycą dla tych roz- 
ważań będą w tym miejscu koncepcje Alexisa de Tocqueville’a, obecne szczególnie w jego O demokracji w Ameryce - autora o ugruntowanej pozycji w gronie klasycznych liberałów i teoretyków polityki, jednak nieco zapoznanego, jeśli chodzi o socjologię ekonomiczną.

Niniejszy artykuł ma dwa cele. Po pierwsze, wykazanie, a raczej przypomnienie niedocenianego prekursorstwa Tocqueville’a w dziedzinie ekonomicznej socjologii polityki; „zgodność sensową" jego myśli o demokracji amerykańskiej z teoriami public choice rozwijanymi od lat 60. XX wieku na Uniwersytecie w Virginii w USA. Zwrot ku klasykom nie musi oznaczać tylko antykwarycznego wspomnienia; twórcze i poważne potraktowanie starych koncepcji może dawać płodne poznawczo rezultaty. W rzeczy samej, francuski liberał zdaje się przezwyciężać niektóre, zbyt uproszczone, założenia standardowego wyboru publicznego. Drugim celem jest przedstawienie konkretnych argumentów na rzecz tezy o nieefektywności rządów demokratycznych. Na bazie założenia o interesie własnym/ racjonalnej ignorancji/irracjonalności wyborców zwolennicy public choice formułują wiele hipotez odnośnie negatywnych skutków wybierania rządzących na drodze powszechnego głosowania. Wybrano jedną z nich, mianowicie problem rozrostu sektora publicznego. Według wielu teoretyków, demokracja jaką znamy posiada w sobie mechanizmy napędzające popyt na coraz większą redystrybucję, co nie przysługuje się dobrze społeczeństwu i gospodarce. W szczególności skoncentrowano się na modelowej schematyzacji rozważań Tocqueville’a przeprowadzonej przez Alana Peacocka oraz poddano go krytyce. Jak zobaczymy, Tocqueville stoi w rozkroku pomiędzy tym, co można nazwać klasyczną teorią wyboru publicznego (Caplan 2006: 94-95) - teorią per se ekonomiczną, tzn. wykorzystującą ustalenia ekonomii (neo)klasycznej, którą Tocqueville znał z pism np. J. B. Saya) a bardziej zsocjologizowanym podejściem do strefy styczności polityki i gospodarki.

W pierwszej części artykułu bardzo szkicowo zaprezentowano podstawowe założenia teorii racjonalnego wyboru (której wybór publiczny jest szczególną postacią), potrzebne do późniejszego uchwycenia stanowiska Tocqueville’a w kwestii założenia o maksymalizowaniu interesu własnego oraz racjonalności na przykładzie obserwacji społeczeństwa amerykańskiego lat 30. XIX wieku, co jest treścią drugiej części. Odpowiednie elementy szkoły wyboru publicznego będą konsekwentnie wprowadzane w miarę wywodu. Ostatnia część poświęcona jest tzw. „krzyżowi Tocqueville’a”, czyli reprezentacji (w formie graficznego modelu) rozważań francuskiego socjologa na temat rozrostu wydatków rządowych. 


\section{Ramy pojęciowe podejścia ekonomicznego}

Wspólnym rdzeniem dla public choice i teorii racjonalnego wyboru są założenia zapożyczone z neoklasycznej mikroekonomii. Z czterech składników wymienionych przez Jamesa Colemana interesują nas właściwie tylko dwa najważniejsze (1994: 146-147):

1. Metodologiczny indywidualizm - postulat wyjaśniania działań społecznych na poziomie jednostkowym, odwołując się do działań indywidualnych jednostek, gdyż tylko one działają i tworzą całości oraz systemy społeczne. Kompleksowe wyjaśnienie musi brać pod uwagę wpływ systemu na orientacje aktorów, same indywidualne działania oraz działania zagregowane, które skutkują zmianami na poziomie systemowym.

2. Zasada aktorów maksymalizujących, czy też optymalizujących - według której „jednostki działają po to, aby maksymalizować użyteczności” (czyli interes własny), podobnie jak w Weberowskim działaniu celoworacjonalnym, jednostki są zorientowane na dany cel i do jego osiągnięcia dobierają odpowiednie środki, takie, które są postrzegane przez nie jako najbardziej efektywne.

Public choice jako wariant rational choice (Wilkin 2012: 14) oczywiście podziela te założenia, z tym, że zamiast tradycyjnie analizować zachowania i instytucje sensu stricto ekonomiczne, w sferze gospodarki rynkowej, wybór publiczny bada problematykę kolektywnego podejmowania decyzji poprzez mechanizmy polityczne (Ibid: 10-11), m. in. demokratycznego głosowania powszechnego, które decyduje o „gospodarowaniu wspólnymi zasobami", jakimi są np. wydatki publiczne.

Poprzestanę na tej pobieżnej charakterystyce, gdyż celem tego artykułu nie jest ani całościowe omówienie, ani też kompleksowa analiza krytyczna wraz ze wskazaniem oczywistych ubytków perspektywy public choice, doskonale widocznych dla socjologów (zob. np. Udehn 1996; Tittenbrun 2012: 287-304). Chodzi jedynie o określenie ram współczesnych teorii ekonomiczno-społecznych, na tle których Tocqueville będzie się wyraźniej prezentował. Jak ujrzymy dalej, stanowisko francuskiego myśliciela, mocno empiryczne przecież, jest trochę bardziej zniuansowane, akcentujące kwestie ważne dla socjologii. Nie przypadkiem kilku badaczy wskazało go jako jednego z protoplastów teorii wyboru publicznego (Wade 1985; Forte 2005).

Socjolog Jon Elster we wstępie do anglojęzycznego tłumaczenia Dawnego ustroju i rewolucji, zadał pytanie: „Czy Tocqueville był teoretykiem racjonalnego wyboru?” (Elster 2011: xv). Pytanie może wydawać się retoryczne, biorąc pod uwagę to, iż sam Elster 
poświęcił całą książkę na dowiedzenie, że Tocqueville był pierwszym poważnym analitykiem społeczeństwa, szukającym w nich mikromechanizmów, a nie ogólnych praw, i że był wolny od przesądów holizmu, organicyzmu, funkcjonalizmu i teleologii (Elster 2009: 6). Cokolwiek by o tym nie sądzić, prawdą jest, że od racjonalnego wyboru jest tylko krok do teorii wyboru publicznego. Jako że analiza amerykańskiego systemu politycznego zajmuje kluczowe miejsce w pisarstwie Tocqueville’a, warto się jej przyjrzeć przez pryzmat współczesnej teorii public choice, czyli swoistej ekonomicznej socjologii polityki.

\section{Komponent pierwszy: interes własny}

W Ameryce sportretowanej przez Tocquevillea namiętne umiłowanie dobrobytu materialnego jest wszechobecne (Tocqueville 1996b: 165). Rzecz jasna nie jest ono uczuciem jedynym, „lecz powszechnym, i jeżeli nawet nie u wszystkich się jednakowo objawia, żywią je wszyscy" (Ibid: 138). Warto zauważyć, że jest to teza mocniejsza niż zwykłe maksymalizowanie użyteczności, gdzie w duchu subiektywizmu nie jest powiedziane, co ma być dla jednostek użyteczne. Nie ma tu jednak wątpliwości: w egalitarnym układzie społecznym, umysł „człowieka demokratycznego” kieruje się ku wartościom czysto materialnym, wręcz pieniężnym: „bez reszty pochłaniają [go] zabiegi zmierzające do zaspokojenia wszystkich potrzeb ciała i wprowadzenie drobnych udogodnień życiowych" (Ibid.). Ilustracją tego niech będzie płacenie czynszu w społeczeństwie arystokratycznym w porównaniu $\mathrm{z}$ demokratycznym. $\mathrm{W}$ arystokracjach robi się to za pomocą pieniądza, ale również szacunku, przywiązania i innych osobistych usług. W demokracjach używa się tylko pieniądza (Ibid: 200); „interes” jest traktowany w sensie dosłownym, jako coś, na czym otwarcie robi się majątek. Instytucja, która kiedyś była poddana wielu społecznym obostrzeniom, teraz została „zekonomizowana”, utowarowiona.

Centralną rolę w rozważaniach na temat interesów odgrywa doktryna dobrze pojętego interesu (intérêt bien entendu). Za tą nazwą kryje się rozpowszechniona w krajach demokratycznych ideologia potocznego utylitaryzmu, głosząca iż to, co dobre, uczciwe i mądre, jest również korzystne i użyteczne w bardziej materialnym sensie. Kiedy kończy się epoka „ślepych poświęceń i instynktownych cnót” (Ibid: 134), a dominację uzyskuje „maksyma głosząca, że człowiek jest najlepszym sędzią swoich prywatnych spraw” (Tocqueville 1996a: 66), to jedynym środkiem do uzyskania spoiwa społecznego i współdziałania różnych jednostkowych, skonfliktowanych interesów jest odwołanie się do dobrze rozumianego interesu. Im większa równość kondycji, tym bardziej „jakaś nieodparta siła każe człowiekowi skupić się na sobie samym". Zadaniem edukacji demokratycznej i władzy 
politycznej jest nie walka z ową siłą, gdyż oznaczałoby to walkę z samą demokracją, ale wyzyskanie jej na rzecz szerszego, publicznego przedsięwzięcia, a nie tylko realizacji egoistycznych pragnień. Zaczynają stosować to religie (Tocqueville 1996b: 135-137), a przede wszystkim prawodawcy: „dążąc do zapewnienia wykonywania ustaw, najczęściej odwołują się więc do interesu osobistego" (Ibid: 79).

Tocqueville jest świadom, że opisane wyżej interesy nie są jedyną motywacją działań człowieka: dlatego mówi również o namiętnościach, ideach czy nawykach (Swedberg 2005: 35). Wyczuwa się napięcie, gdy myśliciel zastanawia się, czy działanie jednostek bardziej determinuje struktura społeczna czy powszechne w ludziach dyspozycje psychiczne:

„Spotkałem w Ameryce te same namiętności, które oglądamy w Europie. Są one po prostu właściwe ludzkiemu sercu albo też układowi społecznemu demokracji. Toteż w Stanach Zjednoczonych odnalazłem ten sam niepokój serca, który jest właściwy ludziom posiadającym mniej więcej równe możliwości i równe szanse awansu społecznego. Odnalazłem demokratyczną zawiść wyrażającą się na tysiąc sposobów. Zauważyłem, że ludzkie poczynania pełne są tego samego zarozumialstwa pomieszanego $\mathrm{z}$ ignorancją. Wywnioskowałem $\mathrm{z}$ tego, że ludzie narażeni są w Ameryce na te same niedole i skazani na tę samą niedoskonałość co wszędzie" (Tocqueville 1996a: 318).

Tocqueville twierdzi jednak, że to interes jest główną siłą napędową, a przynajmniej za taką powinien być uznawany. Postrzega modelowego „człowieka interesu” (który może być również nazwany homo economicus) jako przydatną abstrakcję, typ idealny, szczególnie użyteczny przy badaniu demokracji:

„Jestem przekonany, że w narodach demokratycznych geniusz, przywary i cnoty pewnych osób opóźniają lub przyspieszają naturalny bieg losów społeczeństwa, wszelako te przypadkowe i drugorzędne przyczyny są nieskończenie bardziej różnorodne, ukryte, skomplikowane, mniej potężne i w konsekwencji trudniejsze do odróżnienia i do zbadania w czasach równości niż w czasach arystokracji, kiedy to wystarczy zanalizować poszczególne działania jednej lub kilku osób na tle ogólnych wydarzeń" (Tocqueville 1996b: 92)

Abstrahowanie od partykularnych wpływów, a kierowanie się ku czynnikom ogólnym (jak np. natura ludzka) jest więc zabiegiem celowym. Po pierwsze dlatego, że w czasach równości - homogenizacji społeczeństwa - indywidualne wpływy są znacznie trudniejsze do uchwycenia; po drugie, ponieważ w demokracji idee ogólne mają faktycznie większe znaczenie i moc wyjaśniającą (Ibid.). Teza o prymacie interesu własnego w jego 
czystej formie jest zatem ograniczona do warunków demokracji (Swedberg 2005: 46), co zbliża Tocqueville’a do stanowiska historyzmu.

Warto zauważyć, że podobnie twierdzą ojcowie teorii wyboru publicznego, James Buchanan i Gordon Tullock, odpowiadając na pytanie, jakie jednostki powinny zamieszkiwać ich modelowe społeczeństwo, by można było analizować je narzędziami public choice z jak największą trafnością. Formułują postulat o ekwiwalencji wszystkich zewnętrznych cech jednostek, którego empirycznym przykładem jest naród drobnych posiadaczy, jaki istniał w Stanach Zjednoczonych w 1787 r. (Buchanan, Tullock 1999: 14). Ameryka pierwszej połowy XIX w. opisana przez Tocqueville’a nadal była takim krajem: w 1830 r. (kilka lat przed wizytą sławnego Francuza) 91\% ludzi mieszkało na wsi, a 70\% siły roboczej związane było z rolnictwem (Dahl 2012: 358). Co prawda Buchanan i Tullock dodają, że to zbyt restrykcyjne założenie i nie trzeba go przyjmować, aby z powodzeniem zastosować perspektywę wyboru publicznego (1999: 14), niemniej jednak potwierdza to słuszność spostrzeżeń Tocqueville’a oraz może dowodzić relatywnej historycznej ograniczoności tej koncepcji.

\section{Komponent drugi: racjonalność w polityce}

Przedpolitycznym fundamentem systemu demokratycznego, jego „konstytucją” w rozumieniu zestawu reguł przyjętych z góry, w ramach których będą się odbywały procesy działań zbiorowych (Buchanan, Tullock 1999: xvii) jest zasada suwerenności ludu. Według niej „każdy człowiek dysponuje taką samą częścią suwerennej władzy i na równi z innymi bierze udział w rządzeniu państwem" (Tocqueville 1996a: 65). Skąd się bierze u członków społeczeństwa zgoda na podzielenia się władzą? Otóż nie tylko dlatego, że konstytuuje to nienaruszalne, powszechnie uznawane granice, wewnątrz których powołuje siebie społeczeństwo (Buchanan, Tullock 1999: 7), ale przede wszystkim po to, aby zdobyć użyteczne środki służące do maksymalizowania własnego interesu (Tocqueville 1996a: 65). Społeczny podział pracy stał się tak rozwinięty, splatając ze sobą przeciwstawne interesy wielu jednostek, że jedynym sposobem rozdysponowywania bogactwa na własną korzyść staje się wybór kolektywny (collective choice), na czele z powszechnymi wyborami. „Wybierając prawodawców lud uczestniczy tym samym w kształtowaniu prawa, a wybierając urzędników sprawujących władzę wykonawczą - w ich stosowaniu [...] Lud rządzi amerykańską rzeczywistością polityczną tak, jak Bóg rządzi wszechświatem - jest zarazem racją i kresem wszystkich rzeczy i wszystko pochodzi od niego i wszystko do niego powraca" (Ibid: 59). 
Suwerenne samorządzenie ludu wynika z założenia o równości wszystkich obywateli: „ludzie zostają uznani za jednakowo światłych, cnotliwych i silnych” (Ibid: 65). Czy jednak demokracja urzeczywistnia owy Rousseauowski ideał, w którym oświecony lud podejmując decyzje oparte o zasadę większości reprezentuje sobą wolę powszechną, tożsamą z dobrem publicznym? Słowem - czy większość może się mylić? Tocqueville otwarcie mówi, że powszechne wybory mają pewne zalety, ale gwarancja dokonania słusznego wyboru do nich nie należy (Ibid: 203). Więcej, demokracja jest gwarantem, że na stanowiska decydentów nie będą wybierani ludzi wartościowi i cnotliwi (Ibid: 202). Używając współczesnej terminologii - dostrzega problem niedoskonałej informacji. Rynek idei politycznych jest tak ogromny, że dogłębne zapoznanie się ze wszystkimi propozycjami jest zbyt czasochłonne. Jest ponadto tak skomplikowany; istnieje tyle wzajemnie wykluczających się poglądów, że jednostkę taka sytuacja przytłacza. Stwierdza, że skoro zawodowi ekonomiści, politolodzy czy prawnicy poświęcają całe życie na zgłębianie różnych idei, i mimo to nadal toczą spory o to, które z nich najlepiej oddaje rzeczywistość, to co on, maluczki, może wiedzieć? (Ibid.) Można coraz szerzej rozpowszechniać informację - „ułatwiać dostęp do wiedzy, ulepszać metody nauczania czy obniżać opłaty” (Ibid: 201) - za pomocą prasy (a dziś moglibyśmy dodać także: radia, telewizji, Internetu) - do tego stopnia, że dostęp do niej stanie się właściwie darmowy. Dla Tocqueville’a koszty dostępu mogą być zerowe, to co się liczy to koszty konsumpcji (zapoznania się) dobra jakim jest wiedza. Tym kosztem jest czas.

„Cokolwiek by się uczyniło, podniesienie poziomu wykształcenia społeczeństwa powyżej pewnej granicy jest niemożliwe [...] nigdy nie osiągniemy bowiem stanu, w którym ludzie kształciliby się i rozwijali swą inteligencję, nie poświęcając na to dużo czasu” (Ibid.), ten bowiem jest dobrem jak każde inne i człowiek „musi go oszczędzać, tak jak oszczędza inne rzadkie zasoby" (Mises 2015). Widzimy więc, że założenie o posiadaniu doskonałej informacji przez podmioty biorące udział w procesie wyborczym, o „mądrości tłumu" jest dla Tocqueville’a całkowitą fikcją - uniemożliwia to przyrodzona ograniczoność ludzka. O ile na wolnokonkurencyjnym rynku jest ona redukowana z uwagi na to, że rolę sygnałów informacyjnych i zagregowanej wiedzy pełnią ceny (zob. Hayek 1998), to w przypadku państwa - rynku usług politycznych,

„asymetria informacji jest poważnym problemem. W tym przypadku mamy do czynienia z dobrze znanym faktem, że ludzie działając jako wyborcy mają tendencję do bycia «racjonalnymi ignorantami» w kwestii niemal wszystkich 
poczynań rządu. W rzeczywistości działania rządu są tak wszechogarniające, że żaden ludzki umysł nie jest w stanie pojąć nawet najmniejszego ułamka tego, co robi rządu kraju wielkości Stanów Zjednoczonych. W konsekwencji specjalne grupy interesu dominują wszystkie demokratyczne rządy; rządowe wydatki, opodatkowanie, zadłużanie się oraz możliwości władzy ustawodawczej są w zasadzie nieograniczone" (DiLorenzo 2014).

Pojawiło się kolejne pojęcie ze słownika public choice - racjonalna ignorancja. Wykazuje ono pewną zbieżność z Tocqueville’owskim rozumieniem indywidualizmu, którego konsekwencje są przede wszystkim natury politycznej (Swedberg 2005: 38). Indywidualizm to swoiste przeracjonalizowanie, mające źródło w demokratycznej równości (Tocqueville 1996b: 107): im większa owa równość, tym ważniejszy staje się interes własny. Jednostka tak bardzo zaczyna się nim kierować, że czuje (racjonalnie), iż jako jeden z wielu milionów wyborców nie ma żadnego wpływu na politykę, usuwa się więc w cień swojej rodziny oraz przyjaciół i się stamtąd nie wychyla; ma w końcu wystarczający majątek do stworzenia prywatnego, samowystarczalnego mikroświata (Ibid: 107-109). „Ludzie ci nikomu nic nie zawdzięczają i od nikogo niczego nie oczekują; przywykli do tego, by myśleli o sobie, i są przekonani, że ich los leży w ich własnych rękach” (Ibid: 109). Po co więc mają interesować się „społeczeństwem”? W ich przekonaniu nie posiądą z tego żadnego zysku. Zupełnie tak samo jest według wyboru publicznego: „Wyborcy w ustroju demokratycznym pozostaja częściowymi ignorantami $w$ zakresie wiedzy o kandydatach i zajmowanych przez nich pozycjach wyborczych, ponieważ postępowanie takie leży w ich interesie (jest «racjonalne»)" (Gunning 2001: 161). Takie mechanizmy oznaczają absencję nie tylko w wyborach, ale ogólnie w sferze publicznej, a nawet jeśli nie, to i tak obywatele będą osądzać polityków nie według konkretnej, pogłębionej wiedzy o ich programie, ale „na szybko”, „na podstawie najbardziej widocznych cech” (Tocqueville 1996a: 202). Mass media czasów kampanii wyborczej opanowane są przez chwytliwe slogany i umalowanych kandydatów, a na „debatach" czas przeznaczony na wypowiedzi liczy się w sekundach.

Tocqueville zgodziłby się ze szkołą wyboru publicznego także w tym, że człowiekiem rządzą te same motywacje bez względu na to, czy działa w sferze prywatnej (na rynku) czy publicznej (Buchanan, Tullock: 1999: 19). Sfera polityczna w tym ujęciu staje się odwzorowaniem rynku gospodarczego: politycy chcą zostać wybranymi na kolejną kadencję, a zatem muszą maksymalizować polityczne poparcie, co skutkuje produkcją ustawodawstwa zaspokajającego popyt konsumentów - wyborców. A największą siłę nabywczą 
posiadają ci obywatele, którzy mają determinację do stowarzyszania się, przystępowania do grupy interesu i lobbowania za prawami, które dla nich będą korzystne. Tak zwane dobro publiczne nie ma tu nic do rzeczy (Tittenbrun 2012: 276), chyba że jako zasłona dymna. Tocqueville pisze, że „zwyczaje życia prywatnego przenikają do życia publicznego” (Tocqueville 1996a: 219), oraz że „prywatny interes, który w namiętnościach politycznych odgrywa zawsze największą rolę, jest tu zręczniej ukryty pod osłoną sprawy publicznej, a zdarza się nawet niekiedy, że pozostaje ukryty przed wzrokiem ludzi, którymi powoduje” (Ibid: 177).

\section{Rozrost sektora publicznego jako prawo ruchu demokracji}

Wprowadzenie coraz powszechniejszego prawa wyborczego łączy się z tym, że więcej ludzi głosuje i ma wpływ na poziom podatków i redystrybucji, co z kolei prowadzi do problemu rozrostu sektora państwowego. Są to kwestie kluczowe dla współczesnego państwa dobrobytu, które Tocqueville zauważył, gdy jeszcze mało kto o nich myślał. W 1870 r. (30 lat po ukazaniu się drugiego tomu O demokracji...) wydatki rządowe w USA wynosiły 7,3\% całego PKB (Higgs 2008), podczas gdy w 2014 aż 41,6\% (za: Wikipedia, Government spending). Wzrost podatków i wydatków państwa zajmnie szczególne miejsce w kontekście modelowej formalizacji twierdzenia Tocqueville’a dokonanej przez Alana Peacocka w duchu nowoczesnej analizy wyboru publicznego (Peacock 1997). Są jednak u francuskiego teoretyka pewne ambiwalencje odnośnie (nie)ograniczoności ruchu w stronę coraz większego fiskalizmu, które również będą zaznaczone ${ }^{1}$.

\section{Wariant optymistyczny}

Francuski myśliciel generalnie podziela zdanie klasycznych ekonomistów angielskich w sprawie zbawiennego wpływu własności na poziom moralny i intelektualny człowieka. Dla nich, zachowanie zasad wolności gospodarczej stało wyżej niż wolności polityczne. Skoro powszechne prawo wyborcze oznacza brak jakiegokolwiek cenzusu majątkowego, to naturalne wydawało się - w opinii np. Davida Ricardo - że należy wykluczyć z głosowania ubogich, nie posiadających własności, ponieważ będą oni starali się - a leży to w ich interesie - pozbawić własności tych posiadających (Peacock 1997: 43). W imię wolności gospodarczej ogranicza się wolność polityczną. Ale jest to rozwiązanie tymcza-

\footnotetext{
${ }^{1}$ Zob. krytykę łatwo kwantyfikowalnych wskaźników rozrostu rządu w pracy Roberta Higgsa (Higgs 1989: 20-34). Tocqueville był tego świadom i równie mocno jak na sferę redystrybutywną zwracał uwagę na sferę regulatywną państwa (Zob. Tracz-Tryniecki 2009: 199-211). Przywołanie tego faktu może nieco osłabiać zarzut, jakoby Tocqueville krytykując lud jedynie reprezentował interesy burżuazji przeciwko „roszczeniowym” grupom społecznym.
} 
sowe; wraz z postępem rośnie bowiem także baza moralna i intelektualna społeczeństwa, możliwe też staje się stopniowe przyznawanie praw wyborczych kolejnym grupom społecznym bez obawy, że będą wrogo nastawione do mniejszości posiadającej własność podlegającą opodatkowaniu (Ibid.)

Podobnie sądzi Tocqueville, pisząc o dobroczynnych skutkach, jakie u człowieka wywołuje posiadanie własności prywatnej: „Proletariusze to ci, którzy nie mają żadnej własności oprócz swoich rąk. Ale od kiedy posiądą małą piędź ziemi, nawet bardzo małą, czyż nie zauważysz jak zmienią się ich idee i zwyczaje? Czyż to nie jest oczywiste, że wraz z własnością nabierają oni nadziei na przyszłość?” (Tocqueville 1835, cyt. za: Fraile 2016: 6).

Tocqueville dzieli z ekonomistami również sceptycyzm co do tego, by ludzie pozbawieni własności lub po prostu biedni (którzy zawsze stanowią większość), byli oszczędni i nie starali się wyzyskać publicznych środków do poprawy swojej sytuacji (Tocqueville 1996a: 214). Niestety, powszechne (w tamtych czasach w USA tylko dla białych mężczyzn) prawo wyborcze stwarza sytuację nazywaną dzisiaj popytem na redystrybucję (Peacock 1997: 44):

„Przyjmijmy wreszcie, że trzecia klasa [najbiedniejszych] tworzy prawa: wydatki publiczne prawdopodobnie wzrosną, miast się zmniejszyć, a to z następujących przyczyn: ponieważ przeważająca część ludzi, którzy wtedy przegłosowują ustawy, nie posiada żadnej własności podlegającej opodatkowaniu, wszystkie pieniądze wydane w interesie społeczeństwa mogą im przynieść jedynie korzyść, nie czyniąc żadnej szkody. Ci zaś, którzy mają niewielki majątek, łatwo znajdą sposoby na stworzenie takiej formuły podatkowej, która ugodzi tylko w bogatych, a biednym przyniesie wyłącznie korzyści - czego nie przeprowadziliby bogaci, gdyby mieli władzę w rękach” (Tocqueville 1996a: 214).

Modelowa reprezentację tych rozważań na osi (rysunek 1) została nazwana przez jego twórcę, Alana Peacocka, „krzyżem Tocqueville’a” (Peacock 1997: 47). Oczywiście jest to model bardziej dydaktyczny, niż ściśle naukowy, i służy tylko do ilustracji mechanizmu opisanego na kartach $O$ demokracji....

Zgodnie z założeniami Tocqueville’a, w tym modelu stosunek wysokości podatków do PKB jest funkcją poszerzania się bazy wyborców oraz nierównomiernego rozłożenia dochodów w społeczeństwie. Rząd podejmuje działania na bazie większościowego głosowania swoich wyborców. Wyborcy maksymalizują swoją użyteczność poprzez maksymalizację swojego dochodu. Wyborcy z dochodem poniżej mediany wybierają redystry- 
bucję, podczas gdy ci z dochodami powyżej mediany preferują niższe podatki i mniejszą redystrybucję. Rozstrzygający głos ma wyborca środkowy (medianowy). (Peacock 1997: 46).

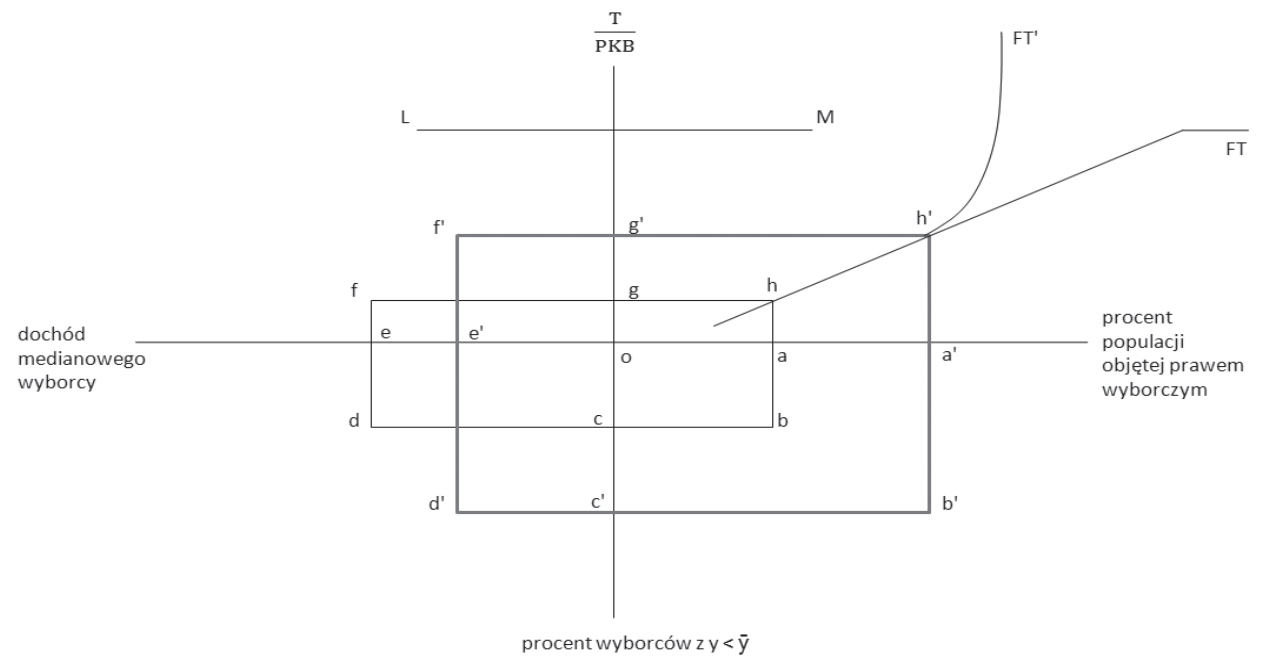

\section{Rysunek 1: Krzyż Tocqueville’a}

(gdzie $\frac{T}{P K B}$ to procentowy stosunek wysokości podatków do PKB, y - dochód, a y - średni dochód) Źródło: Fraile 2016: 24; zob. też uproszczoną wersję w: De La Iglesia 2004.

Prostokąt abdfh jest wyjściowym stanem „równowagi”. Załóżmy, że punkt $a$ określa, iż 30\% populacji jest objęte prawem wyborczym. Wyznacza on również procent wyborców z dochodami poniżej średniej (oc). Zakres populacji wyborców oraz rozkład dochodów pozwala oznaczyć dochód medianowego (środkowego) wyborcy (oe), co z kolei umożliwia zaznaczenie wysokości podatków w stosunku do PKB (og).

Rozważmy teraz sytuację, gdy rozszerzają się prawa wyborcze. Liczba wyborców zwiększy się do $a^{\prime}$, równocześnie zwiększając liczbę wyborców z y $<\bar{y}$ (tzn. dochodem poniżej średniej - więcej wyborców jest ludźmi relatywnie biednymi) - linia oc'. Dochód medianowego wyborcy spadnie (oe'), co spowoduje przesunięcie w górę wysokości opodatkowania $\left(o g\right.$ '). Końcowym stanem społeczeństwa jest prostokąt $a^{\prime} b^{\prime} d^{\prime} f^{\prime} h$ ' z szerszym prawem wyborczym, ale i większymi podatkami (Peacock 1997: 47-48).

Warto w tym miejscu zrobić dygresję w kierunku tych, którzy winią za taki stan rzeczy „Zawodność polityków” (podobnie do „Zawodności rynku” i „zawodności państwa”), którzy w ich opinii nie potrafią lub nie chcą realizować „prawdziwych” preferen- 
cji swoich wyborców w praktyce politycznej, prowadząc zamiast tego rozgrywki partyjne i nie rozliczając się ze swoich obietnic z wyborcami. Według Tocqueville’a, gdy ordynacja wyborcza jest oparta na okręgach jednomandatowych, jak w Stanach Zjednoczonych, politycy faktycznie służą jako przekaźniki woli obywateli, ich podmiotowość jest ograniczona do minimum (Fiori 2005: 47); „wszystkie szanse jego kariery tkwią w okręgu, jaki reprezentuje”, i dalej: „Jest więc rzeczą naturalną, że w krajach demokratycznych członkowie zgromadzeń politycznych myślą bardziej o swoich wyborcach niż o swojej partii [...] tymczasem to, co trzeba powiedzieć, by spodobać wyborcom, nie zawsze pokrywa się z tym, co należałoby zrobić, by dobrze służyć poglądom politycznym, jakie wyznają" (Tocqueville 1996b: 96).

Powracając do modelu: w opinii Peacocka (i to jest ten optymistyczny element) wzrost fiskalizmu (FT) ma swój kres (linia $L M$ ). Na poparcie przywołuje słowa Tocqueville’a o tym, że wraz z postępem społecznym i upowszechnianiem się własności, wyborcy - we własnym interesie - utemperują dalsze zwiększanie podatków, ponieważ sami by pod nie podlegali:

„Nadużycia demokracji stają się zresztą rzadsze, w miarę jak lud się bogaci, ponieważ, z jednej strony, mniej potrzebuje wówczas pieniędzy ludzi bogatych, z drugiej zaś, napotyka na więcej przeszkód w próbach uchylenia się od płacenia podatków. Dlatego powszechne wybory mogą być mniej niebezpieczne we Francji niż w Anglii, gdzie prawie całe bogactwo podlegające opodatkowaniu jest skupione w rękach niewielu ludzi. Ameryka zaś, w której przemożna większość obywateli to posiadacze, znajduje się pod tym względem w jeszcze lepszej sytuacji niż Francja" (Tocqueville 1996a: 215).

O ile można bronić tego twierdzenia, to jest to z pewnością niepełna wizja przesłania, jakie chciał nam przekazać francuski liberał. Przy pomocy Tocqueville’a można równie dobrze, albo nawet bardziej, udowodnić całkiem przeciwny pogląd.

\section{Wariant pesymistyczny}

Po pierwsze, dotychczasowe fakty historyczne przeczą istnieniu jakiejś granicy wielkości sektora publicznego czy wysokości podatków (zob. np. Hoppe 2006: 64-68, przyp. 41). Również jeśli chodzi o mechanizm „szersze prawo wyborcze = większa presja ku wzrostowi podatków”, to widać, że przebiegał raczej po krzywej FT' niż FT (Fraile 2016: 8). „Sukcesywne zwiększanie zasięgu prawa wyborczego i ostateczne ustalenie powszech- 
nego prawa wyborczego przysługującego wszystkim dorosłym obywatelom doprowadziło [...] do uruchomienia procesu permanentnej redystrybucji majątku i dochodu" (Hoppe 2006: 148). Pośrednio ilustrować to może związek pomiędzy stopniowym kasowaniem cenzusów wyborczych a poparciem dla partii socjalistycznych i socjaldemokratycznych na przełomie XIX i XX w.; np. w Niemczech w 1871, 1903 i 1913 odsetek głosów oddanych na socjalistów wynosił odpowiednio 3\%, 32\% i 46\%, równocześnie z tym traciły poparcie partie liberalne (Ibid., przyp. 144).

Wróćmy jednak do Tocqueville’a i przyjrzyjmy się, jak bardzo poważne wątpliwości stawia demokracji, w kontrze do wcześniej omawianego relatywnego optymizmu co do problemu centralizacji i fiskalizmu. Wychodząc od błyskotliwego zdefiniowania demokracji jako jedynego systemu, „który pozwala człowiekowi głosującemu za podatkiem uniknąć obowiązku jego płacenia” (Tocqueville 1996a: 214), dojdziemy do kluczowej cechy demokracji, jaką jest wysoka preferencja czasowa osób znajdujących się pod jej „panowaniem".

Zatrzymajmy się jednak jeszcze na unikaniu skutków nakładania podatków. Może się to odbywać (oprócz głosowania za podatkami progresywnymi) poprzez przerzucanie kosztów ich zapłacenia na następne pokolenia (Peacock 1997: 38-39). Państwo, inaczej niż przedsiębiorstwo na rynku, posługuje się monopolem na stosowanie przemocy (m. in. wykluczając potencjalnych konkurentów, którzy mogliby się pojawić na rynku „usług państwowych”), a co za tym idzie, może zadłużać się bardzo długi czas bez ograniczeń, finansując dobra i usługi d zisi ej szy m obywatelom, których koszty poniosą obywatele jutrzejsi (tj. następne pokolenia) (Ibid.).

Można zapytać, w duchu public choice - tak jak to czyni Tocqueville - czy w interesie ludzi nie leżałoby zaprzestanie tego procederu? Przecież „w dobrze pojmowanym interesie ludu leży szczędzenie fortun bogatych obywateli, ponieważ kraj traci na ich ogołoceniu” (Tocqueville 1996a: 214). Zaraz jednak dodaje: „Gdyby ogólny interes mógł przeważyć nad namiętnościami i potrzebami chwili, nie byłoby nigdy tyranów ani niedostępnej arystokracji” (Ibid.). Obserwacją o kapitalnym znaczeniu jest to, że owe „namiętności i potrzeby chwili” to normalny stan demokracji. Jon Elster potwierdza te przypuszczenia pisząc jasno, że według Tocqueville’a „demokracje generalnie zniechęcają do dalekowzrocznego myślenia” (Elster 2009: 50). 


\section{$6 / 2017$}

„Kiedy każdy ustawicznie stara się zmienić swoją dotychczasową pozycję, kiedy wszyscy mogą stanąć do ogromnej konkurencji, a fortuny powstają i upadają w kilka chwil pośród wrzawy demokracji, w umyśle człowieka rodzi się myśl o szybkim i łatwym wzbogaceniu się, o wielkich, lekko zdobywanych i lekko traconych dobrach, obraz ryzyka pod wszystkimi jego postaciami. Niestabilność systemu społecznego sprzyja naturalnej niestabilności pragnień. Pośród owych fluktuacji losu teraźniejszość nabiera większych wymiarów. Przesłania przyszłość, która się zaciera, i ludzie chcą myśleć jedynie o jutrze" (Tocqueville 1996a: 162).

Typowi ludzie żyjący w czasach demokracji „niewiele myślą o potomności dzień dzisiejszy pochłania ich bez reszty”. Innymi słowy, mają wysoką preferencję czasową, to znaczy preferują dobra teraźniejsze nad dobra, które są większe, ale późniejsze - czyli mają niższą skłonność do oszczędzania, a wyższą do natychmiastowej konsumpcji (Hoppe 2006: 32).

Hans-Hermann Hoppe, reprezentant szkoły austriackiej w ekonomii wykorzystał koncept preferencji czasowej do wieloaspektowego porównania ze sobą rządów monarchicznych z demokratycznymi. Co prawda, dla niego demokracja jest pewnym stosunkiem własnościowym (w monarchii rząd jest prywatny, w demokracji jest własnością publiczną), w przeciwieństwie do Tocqueville’a, dla którego jest to stan społeczny, ale konkluzje wysnuwa podobne. Demokracja oznacza brak umiaru (Hoppe 2006: 61), „nie potrafi być oszczędna” (Tocqueville 1996a: 216). Polityk - jako tymczasowy zarządca państwa - będzie dążył do maksymalizacji bieżącego dochodu (z pominięciem i kosztem wartości kapitału), co oznacza konsumpcję bogactwa teraz (bo rządzi zwykle co najwyżej dwie kadencje); będzie dążyć do redystrybucji, ponieważ powiększanie dobrobytu jednych kosztem drugich (mniej licznych), to najlepszy sposób na zaskarbienie wdzięczności tych pierwszych, czyli reelekcji (Tocqueville 1996a: 216; Hoppe 2006: 61-69).

Hoppe i Tocqueville różnią się co do przyczyn takiego stanu rzeczy, ale zgadzają się, że w „płynnej”, niestabilnej rzeczywistości, jaką jest demokracja, ludzie zwracają się bardziej ku teraźniejszości niż przyszłości.

Kolejną niezbyt optymistyczną obserwacją jest ta, według której wydatki publiczne rosną stale, w miarę postępu społecznego. Nie chodzi tu tylko o wzrost w liczbach absolutnych, ale o stosunek wydatków do PKB. Postęp sprawia, że „pojawia się mnóstwo potrzeb wcześniej nie odczuwanych, które mogą zostać zaspokojone jedynie za pomocą 
środków państwowych. Stąd pochodzi zjawisko powiększania się kosztów publicznych wraz z postępem cywilizacji i wzrastania podatków w miarę szerzenia się oświaty" (Tocqueville 1996a: 216). Twierdzenie to jest znane jako prawo Wagnera, od nazwiska Adolpha Wagnera, który przedstawił je kilkadziesiąt lat po Tocqueville’u (Fraile 2016: 9).

Jednak prawdopodobnie największą przeszkodą ku temu, by demokracja stała się systemem gospodarnym i szanującym własność innych ludzi, jest pewien fakt społeczny (w terminologii Tocqueville’a - obyczaj) wywierający przemożny wpływ na całe społeczeństwo i na każdą jednostkę z osobna; zadomawia się on w psychice obywateli, którzy cieszą się równością kondycji, od niego to wychodzą i do niego prowadzą wszystkie ich działania. Tym faktem jest umiłowanie równości (Tocqueville 1996b: 104). Kultura demokracji jest kulturą równości, a nie wolności. Nie należy się dziwić, że polityka w demokracjach nie spocznie, póki nie wyrówna wszystkich sfer życia, a przeważająca większość obywateli godzi się na większą równość ( $m$. in. w formie redystrybucji dochodów) w zamian za cenę wolności politycznych; nawet ci, którzy wiedzą o skutkach tych zgubnych decyzji, nie potrafią się im przeciwstawić:

„Nie ma ludzi tak ograniczonych i tak lekkomyślnych, by nie zdawali sobie sprawy, że wynaturzenia wolności politycznej narażają spokój, własność oraz życie poszczególnych obywateli. Natomiast tylko ludzie myślący i przewidujący dostrzegają niebezpieczeństwa, jakie kryje w sobie równość, ale na ogół ich nie sygnalizują. Wiedzą, że nieszczęścia, jakich się obawiają, są na razie odległe, i łudzą się, że dotkną one dopiero przyszłe pokolenia, o które nie muszą się troszczyć" (Tocqueville 1996b: 105).

Co interesujące, hipoteza jakoby ludzie nie tyle musieli głosować za redystrybucją, bo tak im „każe” kierowanie się racjonalną ignorancją czy interesem osobistym, co świadomie chcieli wyższych podatków, większych regulacji itp., została na gruncie ekonomii dopiero niedawno na poważnie rozważona przez Bryana Caplana. Atakuje on dotychczasowe założenia teorii wyboru publicznego o prymacie interesu własnego oraz o racjonalności. Jak w wielu miejscach zostało udowodnione, „głosowanie portfelem” ma małe znaczenie (Udehn 1996: 78-86; Caplan 2006: 18-19); osoby w podeszłym wieku nie są wcale bardziej pro-socjalne od młodszych, a mężczyźni są częściej pro-choice niż kobiety. Większą rolę niż interes pełnią uprzedzenia, skłonności czy ideologie przyjęte na wczesnych etapach socjalizacji. Socjologowie chociażby od Durkheima mogli się dowiedzieć, że 
głosowanie ma wymiar przede wszystkim performatywny, a demokracja stała się świecką religią, niepoddawaną racjonalnemu oglądowi.

Zakwestionowanie racjonalności podejmowanych decyzji także nie jest niczym nowym. Klasyczna teoria wyboru publicznego twierdziła, że wyborcy, będąc racjonalnymi ignorantami, głosują w zasadzie losowo (ściślej: zagregowane preferencje nie mają charakteru systematycznego wzoru); zgodnie z prawem wielkich liczb ich różnice się znoszą, a o wyniku wyborów decyduje przekonanie zdyscyplinowanej mniejszości, zrzeszonej w sitwy i grupy interesu, które przeforsowują partykularne projekty na niekorzyść pozostałej części społeczeństwa. Caplan nie kwestionuje tego, ale ciężar winy przenosi na statystycznego wyborcę. Postępuje prawidłowo, gdyż w istocie „czysto racjonalne wybory nie istnieją, ponieważ: postrzeganie prawdopodobnych kosztów i korzyści zależy od pozycji zajmowanej w strukturze społecznej; wartości, obyczaj i tradycja zniekształcają hierarchię preferencji; istnieje wiele czynników społecznych i psychologicznych, które deformują kalkulacje kosztów i korzyści (Turner 2004: 336-337). Wątpliwości może jednak budzić swoisty elitaryzm (Tocqueville powiedziałby: arystokratyzm) Caplana. Swoją kontrpropozycję „racjonalnej irracjonalności” opiera na badaniach porównujących poglądy ekonomiczne laików oraz amerykańskich ekonomistów. Ekonomiści, zdecydowanie bardziej wolnorynkowi niż reszta społeczeństwa, występują u niego jako krynica racjonalności. Caplan ponadto wykazuje, że wiedza ekonomiczna jest podstawową determinantą poglądów pro-rynkowych - im wyższe wykształcenie, najlepiej kierunkowe, tym mniejsze poparcie dla rządowych regulacji (Caplan 2006: 50-94). Nawet jeśli zgodzić się z Caplanem, że postawa wolnorynkowa jest tą właściwą i że edukacja ekonomiczna polega na „sprzątaniu ekonomicznych mitów", to pokłada on zdecydowanie zbyt wielką wiarę w obiektywizm ekonomistów. Wątpliwe jest uznanie ich en masse za szczególnych wolnorynkowców; wystarczy choćby przypomnieć hasło rzucone przez pewnego sławnego ekonomistę w latach 60: „Dzisiaj wszyscy jesteśmy Keynesistami”.

Niemniej, można zauważyć, że propozycja Caplana jest bliższa rzeczywistości i - w pewnych momentach - rozważaniom Tocqueville’a niźli klasyczny wybór publiczny. $\mathrm{W}$ demokracji dogmatem jest umiłowanie równości:

„Społeczeństwa demokratyczne zawsze są rozmiłowane w równości, wszelako zdarzają się epoki, w których ta namiętność graniczy ze stanem upojenia [...] Namiętność równości przenika do głębi serc i zagarnia je bez reszty. Nie próbujcie wtedy mówić ludziom, że oddając się tak ślepo tej wyłącznej namiętności, 
narażają swoje najbardziej żywotne interesy - są głusi. Nie próbujcie im pokazać, jak wolność wymyka się im z rąk, podczas gdy są zajęci czym innym - są ślepi, czy raczej nie widzą nic oprócz jednego dobra godnego pożądania" (Tocqueville 1996b: 105-106).

Czy można zatem - za Heglem - powiedzieć, że lud sam siebie oszukuje? Dotykamy tu kwestii behawioralnej symetrii, czyli przyjętego przez klasyczną teorię public choice założenia o jednolitości preferencji na rynku oraz w polityce. Jeśli zakładamy model człowieka racjonalnego podczas robienia zakupów, musimy uznać, że człowiek będzie zachowywał się tak samo podczas oddawania głosu w wyborach. Sprawa jednak nie jest taka oczywista. Socjologowie powiedzą o różnych - czasem sprzecznych ze sobą - rolach społecznych pełnionych w czasie życia jednostki (Tittenbrun 2012: 288). Co bardziej światli ekonomiści dokonają rozgraniczenia pomiędzy rynkiem a tzw. wspólnym pastwiskiem (Caplan 2006: 206). Wyborca nie wydaje głosów do „kupowania” polityk, on je wrzuca - bezkosztowo - do wspólnej puli, niekoniecznie licząc na jakiś konkretny rezultat. „Lud nie pozwoli żadnemu urzędnikowi, uczonemu, politykowi czy ekspertowi oszukać się w sprawach, które dotyczą jego substancjalnego, czyli majątkowego, podłoża” (Kozyr-Kowalski 1997) - takie jest zdanie Hegla, pokrewne ekonomistom, ale także francuskiemu myślicielowi: „Kupiec skwapliwie i bezkrytycznie przyjmie wszystkie idee ogólne dotyczące filozofii, polityki, nauk i sztuk, jakie zechcemy mu podsunąć. Ale dopiero po sprawdzeniu z dużą powściągliwością przyjmie te, które będą miały związek z handlem" (Tocqueville 1996b: 24). Jednostki działające na rynku odbierają bodźce, które skłaniają je do bycia racjonalnymi. Każda najmniejsza strata skutkująca odczuwaną przykrością, choćby to było przepłacenie za towar w sklepie, wywiera presję na przemyślenie swojego postępowania. $\mathrm{Na}$ „rynku” politycznym, gdzie pojedynczy głos nie ma żadnej „siły nabywczej”, a skutki negatywnych zarządzeń politycznych są rozmyte, rozproszone na całe społeczeństwo, pojawia się popyt na irracjonalność - to znaczy te działania, których jednostka by raczej nie podjęła, gdyby działała na rynku (Caplan 2006: 131-141).

Czy Tocqueville proponuje jakieś remedia na ten dość ponury obraz demokracji? Można „podsunąć obywatelom możliwie najwięcej okazji do współdziałania oraz na każdym kroku wzbudzać w nich poczucie wzajemnej zależności” (Tocqueville 1996b: 113), gdyż inaczej „nie dostrzegają oni wpływu, jaki los państwa może wywrzeć na ich własne życie" (Ibid: 114). Z pewnością w pierwszych latach istnienia Stanów Zjednoczonych (a jeszcze bardziej w czasach kolonialnych) oddziaływanie pojedynczych gmin czy na- 


\section{$6 / 2017$}

wet ludzi na „rzecz wspólną” było znacznie większe niż dzisiaj. W czasach Tocqueville’a (a także naszych) problemem stała się masowość demokracji, skutkująca niezdolnością do zidentyfikowania właściwie rozumianego interesu. Znana jest sympatia Tocqueville’a do dobrowolnych, lokalnych stowarzyszeń. Być może w nich należy szukać jego recepty na postawioną w tej pracy kwestię. Polityka oparta na swobodnym zrzeszaniu się oznaczałaby zatem jakąś formę zdecentralizowanej demokracji bezpośredniej, posiadającą jednak - pamiętając o ostrzeżeniu Tocqueville’a przed tyranią większości - prawo nieuznania za wiążące wyników głosowania przez mniejszość oraz sformowanie własnego stowarzyszenia. Oprócz kryteriów formalnych francuski socjolog akcentuje kryteria treściowe: lokalna polityka powinna zostać uszlachetniona największym ideałem ustroju przeddemokratycznego, mianowicie arystokratyzmem, czyli między innymi świadomością istnienia ludzi niżej od nas sytuowanych, wobec których mamy zobowiązania pomagania i rozwijania ich nie dlatego, że to dla nas opłacalne, ale dlatego, że to moralne. Małe są jednak na to szanse, jeśli ludzie demokratyczni „będą znosili nędzę, jarzmo niewoli, barbarzyństwo, ale nie ścierpią arystokracji” (Tocqueville 1996b: 106).

Niniejsza praca nie stanowi oczywiście pełnego zaprezentowania stanowiska autora O demokracji w Ameryce na temat państwa, ekonomii i demokracji, wiele kluczowych rzeczy znalazło się bowiem w Dawnym ustroju i rewolucji, Raporcie o pauperyzmie czy mniej znanych listach. Mimo to pytania i problemy przed którymi stawał Francuz są dziś - w obliczu rozkładu państwa dobrobytu - aktualne jak nigdy dotąd. Z poglądów Tocqueville’a wyłania się więc wniosek, że choć twierdzenie, iż „demokracja jest sprzeczna z prawami fizyki” (Dukaj 2004: 362) jest być może nadużyciem, to jednak system ten ma wpisaną w sobie immanentną wadliwość, której chyba nie można wyeliminować kierując się prostymi receptami jego apologetów typu wspominanej „na kryzys demokracji - więcej demokracji”.

\section{Bibliografia}

Bartyzel, Jacek. 2009. Śmiertelny bóg Demos. Warszawa: Fijorr Publishing.

Berger, Peter L. 1995. Zaproszenie do socjologii. Warszawa: Wydawnictwo Naukowe PWN.

Buchanan, James M., Tullock, Gordon. 1999. The Calculus of Consent. Indianapolis: Liberty Fund.

Caplan, Bryan. 2006. The Myth of the Rational Voter. Princeton i Oxford: Princeton University Press. Coleman, James. 1994. Perspektywa racjonalnego wyboru w socjologii ekonomicznej. W: A. Jasińska-Kania, L. M. Nijakowski, J. Szacki, M. Ziółkowski (red.), Współczesne teorie socjologiczne, t. 1, Warszawa: Wydawnictwo Naukowe „Scholar”, s. 145-164. 
Dahl, Robert A. 2012. Demokracja i jej krytycy. Warszawa: Wydawnictwo Aletheia.

DiLorenzo, Thomas. 2014. Czy asymetria informacji stanowi zawodność rynku? < http://mises.pl/ blog/2014/06/11/dilorenzo-asymetria-informacji-stanowi-zawodnosc-rynku/>, dostęp 13 maja 2015.

Dukaj, Jacek. 2004. Perfekcyjna niedoskonałość. Kraków: Wydawnictwo Literackie.

Elster, Jon. 2009. Alexis de Tocqueville, the First Social Scientist. New York: Cambridge University Press.

Elster, Jon. 2011 Introduction. W: Tocqueville. The Ancien Régime and the French Revolution. New York: Cambridge University Press.

Forte, Francesco. 2005. Sui contributi di Alexis de Tocqueville alla teoria delleconomia pubblica e della politica economica, „Rivista di Politica Economica” vol. 3, s. 41-66.

Fraile, Pedro. 2016. Fiscal pessimism in historical perspective. Tocqueville revisited. $<$ http://e-archivo. uc3m.es/bitstream/handle/10016/23964/wh1609.pdf?sequence=1>, dostęp 1 luty 2017.

Gunning, Patrick James. 2001. Zrozumieć demokrację. Warszawa: Wyższa Szkoła Bankowości, Finansów i Zarządzania im. Profesora Romualda Kudlińskiego.

Hayek, Friedrich von. 1998. Wykorzystanie wiedzy w społeczeństwie. W: Indywidualizm i porzadek ekonomiczny. Kraków: Wydawnictwo Znak.

Higgs, Robert. Crisis and Leviathan. 1987. New York, Oxford: Oxford University Press.

Higgs, Robert. 2008. Government Growth. <http://www.econlib.org/library/Enc/GovernmentGrowth. html>, dostęp 26 sierpnia 2015.

Hoppe, Hans-Hermann. 2006. Demokracja - bóg, który zawiódł. Warszawa: Fijor Publishing.

Iglesia, Jesús De La. 2004. Tocqueville’s cross. W: J. Segura, C. R. Braun (red.), An Eponymous Dictionary of Economics: A Guide to Laws and Theorems Named after Economists. Cheltenham: Edward Elgar Publishing Limited, s. 260.

Kozyr-Kowalski, Stanisław. 1997. Urzędnicy państwa jako stan społeczny. <http://www.staff.amu.edu. $\mathrm{pl}$ / kozyr/urzednicy.htm> , dostęp 28 sierpnia 2015.

Marti, Urs. 2010. Niedotrzymana obietnica demokracji. Warszawa: Instytut Wydawniczy Książka i Prasa.

Mises, Ludwig von. 2015. Czas. <http://mises.pl/blog/2015/04/29/mises-czas/>, dostęp 13 maja 2015.

Peacock, Alan. 1997. Public Choice Analysis in Historical Perspective. New York: Cambridge University Press.

Swedberg, Richard. 2005. Interest. Glasgow: Open University Press.

Tittenbrun, Jacek. 2012. Gospodarka w społeczeństwie. Poznań: Zysk i S-ka Wydawnictwo.

Tocqueville, Alexis de. 1996a. O demokracji w Ameryce, t. I. Kraków: Znak.

Tocqueville, Alexis de. 1996b. O demokracji w Ameryce, t. II. Kraków: Znak. 
Tracz-Tryniecki, Marek. 2009. Myśl polityczna i prawna Alexisa de Tocqueville. Kraków: Księgarnia Akademicka.

Turner, Jonathan H. 2004. Struktura teorii socjologicznej. Warszawa: Wydawnictwo Naukowe PWN.

Udehn, Lars. 1996. The Limits of Public Choice. A Sociological Critique of the Economic Theory of Politics. London: Routledge.

Wade, L. L. 1985. Tocqueville and Public Choice, „Public Choice” 1985, vol 47, s. 491-508.

Wikipedia. 2015. Government spending <https://en.wikipedia.org/wiki/Government_spending\#As _a_percentage_of_GDP>, dostęp 26 sierpnia 2015.

Wilkin, Jerzy. 2012 Teoria wyboru publicznego - homo oeconomicus w sferze polityki. W: J. Wilkin (red.), Teoria wyboru publicznego. Główne nurty i zastosowania. Warszawa: Wydawnictwo Naukowe SCHOLAR. 